\title{
Tremor in neurodegenerative ataxias, Huntington disease and tic disorder
}

\section{Drżenie w ataksjach o etiologii zwyrodnieniowei, w plasawicy Huntingtona ichorobie tikowej}

\author{
Monika Rudzińska, Małgorzata Krawczyk, Magdalena Wójik-Pędziwiatr, Andrzej Szczudlik, Tomasz Tomaszewski \\ Department of Neurology, Jagiellonian University Medical College, Cracow, Poland
}

Neurologia i Neurochirurgia Polska 2013; 47, 3: 232-240

DOI: 10.5114/ninp.2013.35585

\begin{abstract}
Introduction: Tremor is the most prevalent movement disorder, defined as rhythmic oscillations of a body part, caused by alternating or synchronic contractions of agonistic or antagonistic muscles. The aim of the study was to assess prevalence and to characterize parameters of tremor accompanying degenerative ataxias, Huntington disease (HD) and tic disorders in comparison with a control group.

Material and methods: Forty-three patients with degenerative ataxias, 28 with HD and 26 with tic disorders together with 51 healthy controls were included in the study. For each participant, clinical and instrumental assessment (accelerometer, electromyography [EMG], graphic tablet) of hand tremor was performed. Frequency and severity of tremor were assessed in three positions: at rest (rest tremor), with hands extended (postural tremor), during the 'finger-to-nose' test and during Archimedes spiral drawing (kinetic tremor). Based on the mass load test, the type of tremor was determined as essential tremor type or enhanced physiological tremor type.

Results: The incidence of tremor in the accelerometry in patients with degenerative ataxia (50\%) significantly differs from controls $(10 \%)(p=0.001)$. The dominant tremor was postural, low-intense, with 7-Hz frequency, essential tremor $(23 \%)$ or other tremor type $(23 \%)$, while enhanced physiological tremor was the least frequent $(2 \%)$. Tremor in patients with HD and tic disorders was found in $10 \%$ and $20 \%$ of patients, respectively, similarly to the control group. Tremor was mild, postural and of essential tremor type, less frequently
\end{abstract}

\section{Streszczenie}

Wstęp: Drżenie jest najczęściej występującym ruchem mimowolnym, definiowanym jako rytmiczne oscylacje części ciała spowodowane naprzemiennymi lub synchronicznymi skurczami mięśni agonistycznych i antagonistycznych. Celem badania była ocena częstości występowania i charakterystyka parametrów drżenia występującego w ataksjach zwyrodnieniowych, chorobie Huntingtona (HD) oraz chorobie tikowej w porównaniu $\mathrm{z}$ grupą kontrolną.

Materiał i metody: Do badania włączono 43 chorych $z$ rozpoznaniem ataksji zwyrodnieniowych, 28 z HD i 26 z chorobą tikową oraz 51 osób z grupy kontrolnej. U każdego badanego obecność drżenia kończyn górnych określano klinicznie $\mathrm{i}$ aparaturowo [akcelerometr, elektromiografia (EMG) i tablet graficzny]. Częstotliwość i nasilenie drżenia badano w 3 pozycjach: w spoczynku (drżenie spoczynkowe), przy wyciągniętych przed siebie kończynach górnych (drżenie pozycyjne) oraz podczas próby „palec-nos” i rysowania spirali Archimedesa (drżenie kinetyczne). $\mathrm{Na}$ podstawie testu obciążenia określano także rodzaj drżenia jako drżenie typu drżenia samoistnego lub nasilonego drżenia fizjologicznego. Wyniki: Obecność drżenia w ataksjach zwyrodnieniowych w badaniu akcelerometrycznym stwierdzono u ok. 50\% chorych, co różniło się znacznie od grupy kontrolnej (10\%) $(p=0,001)$. Dominowało drżenie pozycyjne o niewielkim nasileniu i częstotliwości ok. $7 \mathrm{~Hz}$, o typie najczęściej drżenia samoistnego (23\%) i drżenia innego typu (23\%), najrzadziej nasilonego drżenia fizjologicznego (2\%). Obecność drżenia w HD i chorobie tikowej stwierdzono odpowiednio u ok. 10\%

Correspondence address: dr n. med. Magdalena Wójcik-Pędziwiatr, Department of Neurology, Jagiellonian University Medical College, 3 Botaniczna St., 31-503 Kraków, Poland, e-mail: stokrotka283@tlen.pl

Received: 14.05.2012; accepted: 10.10.2012 
of enhanced physiological tremor type. No correlation between severity of tremor and severity of disease was found.

Conclusions: The prevalence of tremor is considerably higher among patients with degenerative ataxias compared with $\mathrm{HD}$, tic disorder and the control group. The most common type of tremor accompanying ataxias, HD and tic disorders is essential tremor type.

Key words: degenerative ataxias, Huntington disease, tic disorders, accompanying tremor.

\section{Introduction}

Tremor is the most common involuntary movement, defined as the occurrence of involuntary rhythmic oscillation of body parts due to alternating or synchronous contractions of agonist and antagonist muscles [1]. Tremor can be the major sign of movement disorder, as seen in essential tremor; it can also be one of several major signs, as in Parkinson disease, or may occur only in some cases of specific disorders, e.g. in Wilson disease. Tremor can also occur as a sign of damage within the central or peripheral nervous system (symptomatic tremor) of various aetiologies (stroke, multiple sclerosis, trauma, tumour or neuropathy). Tremor also occurs in advanced stages of multiple neurodegenerative disorders, including Alzheimer disease, Kennedy disease and restless legs syndrome [2]. Additionally, it can be occasionally observed in congenital myoclonus, hereditary neuropathy [3], Huntington disease (HD), especially in Westphal variant [4,5], and in tic disorder [6].

Intentional tremor is one of the predominant signs in spinocerebellar ataxias (SCAs), and other types of tremor (rest or postural tremor) are involved in the clinical picture of particular SCA types, e.g. in SCA-2, 3, $6,7,8$ and 12 [7-10].

In contrast to pathological tremor, which is a sign of a neurological or systemic disorder, the physiological tremor occurring in normal people is a distinct aetiological category worth considering in the differential diagnosis. The latter is tremor with a small amplitude (usually invisible during routine observation) and relatively high frequency $(8-12 \mathrm{~Hz})$, which is typically higher distally and lower proximally. Physiological tremor can be exacerbated due to various factors, both endogenous (e.g. hypoglycaemia, thyrotoxicosis, hypothermia) i $20 \%$ chorych, podobnie jak w grupie kontrolnej. Występujące drżenie było niewielkie, głównie pozycyjne i o typie drżenia samoistnego, rzadziej nasilonego drżenia fizjologicznego. W żadnej badanej grupie chorych nie stwierdzono zależności między nasileniem drżenia a nasileniem objawów choroby podstawowej.

Wnioski: Częstość występowania drżenia w ataksjach zwyrodnieniowych jest znacząco większa w porównaniu z osobami z HD, chorobą tikową i grupą kontrolną. Najczęstszym typem drżenia towarzyszącego ataksjom, $\mathrm{HD}$ i chorobie tikowej jest drżenie o typie drżenia samoistnego.

Słowa kluczowe: ataksje zwyrodnieniowe, choroba Huntingtona, tiki, towarzyszące drżenie.

and exogenous (stress, fatigue, tremorogenic medications, e.g. lithium, tricyclic antidepressants, neuroleptics, caffeine or valproic acid, as well as specific toxins, e.g. mercury, lead or arsenic), and then it is termed enhanced physiological tremor (EPT).

Studies that address the prevalence of EPT in healthy subjects are scarce and their reports are occasionally contradictory due to various methods of tremor recording and divergent age of the studied populations. The prevalence of EPT among healthy subjects reached $10-30 \%$ in several studies [11-14].

The co-occurrence of divergent involuntary movements in one disorder is a typical feature of patients with movement disorders. In HD for example, dystonic movements, as well as motor/vocal tics or myoclonus, are observed in addition to the chorea. Equally rich is the phenomenology of involuntary movements in neurodegenerative ataxias, where cerebellar ataxia is not uncommonly accompanied with dystonia, parkinsonian features, myoclonus or chorea. Thus, the determination of the prevalence of tremor, the most common involuntary movements, in disorders that do not exhibit tremor as a major feature seems to be an interesting question.

The aim of the study was to assess prevalence and to characterize parameters of tremor accompanying degenerative ataxias, $\mathrm{HD}$ and tic disorders in comparison with the control group.

\section{Material and methods}

Participation in this study was offered to all patients diagnosed with neurodegenerative ataxia, $\mathrm{HD}$ or tic disorder, who were treated either in an out-patient clinic or in the Department of Neurology of the University Hospital in Krakow between 2005 and 2009. 
Inclusion criteria consisted of age between 18 and 85 and the diagnosis of one of the above-mentioned disorders. Neurodegenerative ataxias were diagnosed according to the clinical picture, magnetic resonance imaging (MRI), and (in some patients) according to the results of genetic testing for SCA1 and SCA2. Huntington disease was diagnosed clinically and confirmed by the genetic testing; tic disorder was diagnosed clinically.

Exclusion criteria applied to patients comprised a history of alcohol abuse, diagnosis of schizophrenia, depression, dementia or other severe psychiatric disorders, as well as thyrotoxicosis; coexistence of severe systemic or metabolic disorders leading to organ failure, history of drug or heavy metal toxicity, exposure to toxins; malignancies or autoimmune disorders, posttraumatic or other lesions that would preclude assessment of tremor, as well as acute infectious disease.

Exclusion criteria pertinent to control subjects consisted of a history of neurological disorder(s) or the presence of their symptoms in the neurological examination.

The protocol of the study was approved by the local bioethical committee; all subjects signed their informed consent to participate in the study.

Each patient or healthy participant was subjected to a detailed interview, neurological examination and the assessment of tremor. The interview included demographic data (age and level of education), past and current illnesses (including diabetes mellitus, arterial hypertension, ischaemic heart disease, hypercholesterolaemia, liver or renal disease, malignancies), medications and their adverse effects, exposure to toxins, smoking and genetic susceptibility (family history of neurodegenerative disorders or tremor). The detailed interview also included data related to the disease of interest, e.g. age at onset of symptoms, the course of the disease, and localization of symptoms; those data were used to establish the form of the disease.

Besides the standard neurological examination, the following scales were used to assess the severity of movement disorders: (a) International Cooperative Ataxia Rating Scale (ICARS) to assess the severity of ataxia (score range: 0-76); (b) Unified Huntington's Disease Rating Scale (UHDRS) (motor part, score range: 0-60) to assess the severity of chorea; (c) Quantified Staging of Functional Capacities in Huntington's Disease (QSFCHD) to assess the level of dysfunction in that disease (score range: 0-13), and (d) Tourette Syndrome Global Scale (TSGS) to assess the severity of tic disorder (score range: 0-20/50).
Clinical and instrumental assessment of upper limb tremor was performed consecutively in both hands using instruments (accelerometer, EMG, graphic tablet) and appropriate software analysing tremor in the Tremor Assessment Laboratory of the Department of Neurology, Jagiellonian University College of Medicine in Krakow.

The severity of tremor was assessed with the Simple Tremor Severity Scale (grade 0-4). The presence and severity of rest tremor were assessed with the observation of the hand placed comfortably on the thighs of the subject in a sitting position; postural tremor was assessed in the upper limb outstretched in front of the subject and kinetic tremor was evaluated during a 'finger-nose' manoeuvre and while drawing an Archimedes spiral. The frequency of tremor (in $\mathrm{Hz}$ ) was assessed according to the results of accelerometric testing, and the severity of tremor was evaluated according to the recordings made using a graphic tablet, as the tremor severity index on a $0-10$ scale. Based on the study with an accelerometer, three types of tremor were also discerned: EPT type, essential tremor type (ET-T), and tremor of another type. Enhanced physiological tremor and ET-T tremor were diagnosed if one peak only predominated in the tremor frequency spectrum. In case of a greater number of peaks or if the predominant peak could not be identified, tremor of other type was diagnosed. Physiological tremor was differentiated from ET-T tremor by the assessment of the tremor frequency with an accelerometer and simultaneous EMG recording in the outstretched hand before and after the load with a $500-\mathrm{g}$ weight mounted at the level of the wrist. Physiological type of tremor was diagnosed if the frequency of tremor in the loaded hand decreased by more than $1 \mathrm{~Hz}$, and ET-T tremor was diagnosed if no difference in frequency was noted or if the decrease in tremor frequency was smaller than $1 \mathrm{~Hz}[15]$.

Synchronicity of tremor was analysed with the observation of 10-second EMG recording from agonist and antagonist muscles of the forearm. Asynchronicity of agonist and antagonist muscle contractions responsible for the tremor of the hand was diagnosed in case of the marked shift of the bioelectrical activity registered in agonist muscles in relation to the same bioelectric activity of the antagonist muscles in more than $90 \%$ of recorded cycles of bioelectric activity of the studied muscles.

Analysis of tremor with the graphic tablet was performed during Archimedes spiral drawing with an electronic pen according to the pattern provided on the tablet. Lateral deviations from the spiral line in $\mathrm{X}$ and $\mathrm{Y}$ 
axes, as well as the pressure of the pen ( $\mathrm{Z}$ axis), were registered and analysed. Presence of upper limb tremor was established according to the presence of the characteristic peak dominant frequency of the spectrum. This method enables the calculation of the dominant frequency of tremor, amplitude of tremor and the coefficient of tremor intensity; it also provides the computerized assessment of tremor severity on a $0-10$ scale, where 10 indicates the greatest severity of tremor [16].

Quantitative tremor analysis with the accelerometer enables the assessment of tremor in three-dimensional space. This part of the study was performed using a three-axial accelerometer (BIOPACK). The accelerometer was mounted to the proximal phalanx of the third finger with a 'velcro' band. Registration of tremor took 1.5 minutes. Presence of tremor was established according to the occurrence of the characteristic peak dominant frequency of the spectrum. This method was used to assess frequency and severity of tremor.

For EMG testing, superficial electrodes were mounted in standard leads over wrist flexors and extensors (extensor carpi radialis brevis muscle and flexor carpi radialis muscle) [17]. Registration of tremor took 1.5 minutes. The use of superficial EMG enabled the assessment of synchronicity of the contractions within two antagonist muscle groups, i.e. wrist flexors and extensors. Visual assessment of 10-second EMG recording was done independently by two investigators.

In all patients, laboratory studies were performed to exclude other causes of tremor, such as haematological and biochemical disturbances, hormonal disorders (thyroid hormones: $\mathrm{TSH}, \mathrm{T} 3$, and $\mathrm{T} 4$ ) and ceruloplasmin concentration.

\section{Statistical methods}

Results were provided as means and standard deviations for the given variable. The results were entered into the database, and their analysis used the statistical package SPSS. Statistical analysis involved Student $t$-test for continuous variables and $\chi^{2}$ test for categorical variables. A $p$-value of less than 0.05 was considered significant.

\section{Results}

The study included 43 patients with neurodegenerative ataxias, 28 patients with $\mathrm{HD}$ and 26 patients with tic disorder (Table 1). There were 9 patients with genetically confirmed SCA- 1 and 3 patients with genetically confirmed SCA-2 among 43 patients with neurodegenerative ataxia. One patient within the HD group was diagnosed with Westphal variant.

Clinical assessment revealed the presence of tremor in $16(37.2 \%)$ patients with neurodegenerative ataxia, in $3(12.5 \%)$ patients with tic disorder, in $2(7.1 \%)$ patients with $\mathrm{HD}$ and in none of the control subjects. The tremor observed clinically was mild (rated as 1 point on the Simple Tremor Severity Scale) in 8 patients (18.6\%) with neurodegenerative ataxia, in 1 patient with $\mathrm{HD}$ and in 2 patients with tic disorder. Tremor of moderate intensity (2 points) was noted in 6 patients (14.0\%) with neurodegenerative ataxia, in 1 patient with $\mathrm{HD}$ and in 1 patient with tic disorder. Severe tremor (3 points) was observed in 2 patients with neurodegenerative ataxia only.

Accelerometry enabled the registration of tremor in $22(51.2 \%)$ patients with neurodegenerative ataxia and,

Table 1. Characteristics of studied patients and controls

\begin{tabular}{|c|c|c|c|c|}
\hline Diagnosis & Neurodegenerative ataxias & Huntington disease & Tic disorder & Control group \\
\hline Number (women/men) & $\begin{array}{c}43 \\
(20 / 23)\end{array}$ & $\begin{array}{c}28 \\
(15 / 13)\end{array}$ & $\begin{array}{c}26 \\
(8 / 18)\end{array}$ & $\begin{array}{c}51 \\
(19 / 32)\end{array}$ \\
\hline $\begin{array}{l}\text { Age [years]; } \\
\text { mean } \pm \mathrm{SD} \text { (range) }\end{array}$ & $\begin{array}{c}49 \pm 11 \\
(29-67)\end{array}$ & $\begin{array}{c}47 \pm 19 \\
(18-77)\end{array}$ & $\begin{array}{l}28 \pm 7 \\
(19-39)\end{array}$ & $\begin{array}{l}55 \pm 17 \\
(21-79)\end{array}$ \\
\hline $\begin{array}{l}\text { Disease duration [years]; } \\
\text { mean } \pm \mathrm{SD} \text { (range) }\end{array}$ & $\begin{array}{l}6 \pm 9 \\
(1-25)\end{array}$ & $\begin{array}{l}8 \pm 7 \\
(1-30)\end{array}$ & $\begin{array}{l}3 \pm 5 \\
(1-16)\end{array}$ & - \\
\hline $\begin{array}{l}\text { Severity of symptoms } \\
\text { in particular scales } \\
\text { mean (range) }\end{array}$ & $\begin{array}{c}\text { ICARS } \\
22(9-44)\end{array}$ & $\begin{array}{c}\text { UHDRS } \\
16(6-28) \\
\text { QSFCHD } \\
8(3-13)\end{array}$ & $\begin{array}{c}\text { TSGS } \\
1.0 \\
(0.5-2.0)\end{array}$ & - \\
\hline
\end{tabular}

SD - standard deviation, ICARS - International Cooperative Ataxia Rating Scale, UHDRS - Unified Huntington's Disease Rating Scale, QSFCHD - Quantified Staging of Functional Capacities in Huntington's Disease, TSGS - Tourette Syndrome Global Scale 


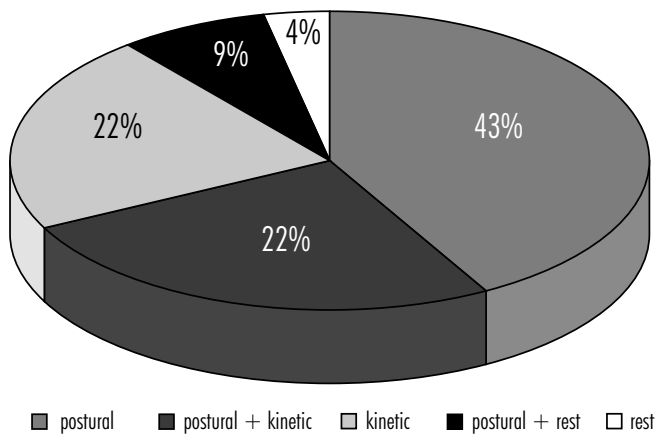

Fig. 1. Relative distribution of various types of tremor among patients with neurodegenerative ataxias

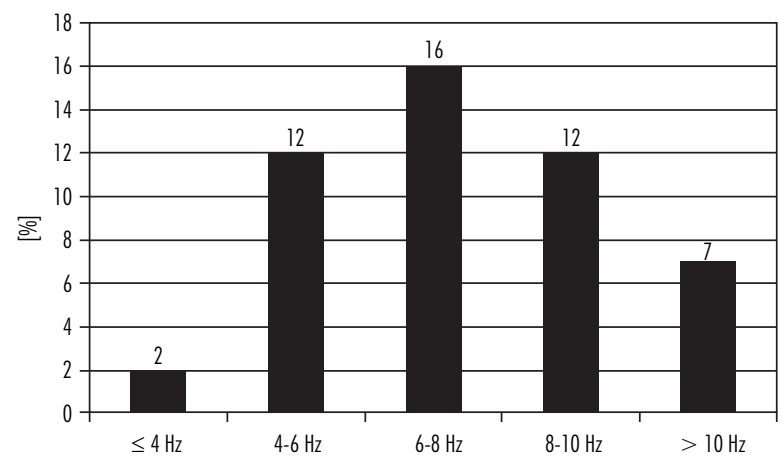

Fig. 2. Prevalence of postural tremor within various frequency ranges in patients with degenerative ataxias similarly to the clinical assessment, postural tremor was the most common one, followed by kinetic tremor and, occasionally, rest tremor. Coexistence of postural and kinetic tremor was noted in 5 patients; postural tremor co-occurred with rest tremor in 2 patients. Figure 1 shows the relative distribution of various types of tremor among patients with neurodegenerative ataxias.

Accelerometry revealed tremor in 3 patients with HD (including postural tremor in 2 patients and rest tremor in another 1), and in 5 patients with tic disorder (including postural tremor in 4 patients and kinetic tremor in another 1).

Postural tremor was registered with accelerometry in $5(9.8 \%)$ subjects within the control group; assessment with the graphic tablet revealed postural tremor in 4 (7.8\%) controls (Table 2 ).

When types of upper limb tremor in neurodegenerative ataxias were analysed, ET-T tremor was diagnosed in $10(23.3 \%)$ patients, EPT in $2(4.7 \%)$ patients, and tremor of the other type was found in 10 (23.3\%) patients. The prevalence of postural tremor within various frequency ranges is shown in Fig. 2, and the severity index of tremor as assessed instrumentally with the graphic tablet is shown in Fig. 3. Among HD patients, ET-T tremor was noted in $2(7.1 \%)$ patients and EPT was found in $1(3.6 \%)$ patient. Among patients with tic

Table 2. Prevalence and characteristics of tremor

\begin{tabular}{|c|c|c|c|c|}
\hline \multirow[t]{2}{*}{ Prevalence of tremor and its characteristics } & \multicolumn{3}{|c|}{ Diagnosis } & \multirow[t]{2}{*}{ Control group } \\
\hline & $\begin{array}{c}\text { Neurodegenerative } \\
\text { ataxias }\end{array}$ & $\begin{array}{c}\text { Huntington } \\
\text { disease }\end{array}$ & $\begin{array}{c}\text { Tic } \\
\text { disorder }\end{array}$ & \\
\hline Clinically, including: & $16(37.2 \%)$ & $2(7.1 \%)$ & $3(12.5 \%)$ & 0 \\
\hline Postural tremor & $10(23.3 \%)$ & $1(3.6 \%)$ & $2(7.7 \%)$ & \\
\hline Kinetic tremor & $5(11.6 \%)$ & 0 & $1(3.9 \%)$ & \\
\hline Rest tremor & $1(2.3 \%)$ & $1(3.6 \%)$ & 0 & \\
\hline Accelerometrically, including: & $22(51.2 \%)$ & $3(10.7 \%)$ & $5(19.2 \%)$ & $5(9.8 \%)$ \\
\hline Postural tremor & $15(34.9 \%)$ & $2(7.1 \%)$ & $4(15.4 \%)$ & $5(9.8 \%)$ \\
\hline Kinetic tremor & $6(14.0 \%)$ & 0 & $1(3.9 \%)$ & 0 \\
\hline Rest tremor & $1(2.3 \%)$ & $1(3.5 \%)$ & 0 & 0 \\
\hline Tremor frequency & $7.4 \mathrm{~Hz}$ & $7.6 \mathrm{~Hz}$ & $7.9 \mathrm{~Hz}$ & $9.8 \mathrm{~Hz}$ \\
\hline As assessed with graphic tablet & $25(58.1 \%)$ & $2(7.1 \%)$ & $5(19.2 \%)$ & $4(7.8 \%)$ \\
\hline $\begin{array}{l}\text { Tremor intensity as assessed with } \\
\text { the graphic tablet; mean (range) }\end{array}$ & $2.9(1-8)$ & $2.0(1-3)$ & $2.1(1-5)$ & $2.0(1-3)$ \\
\hline
\end{tabular}


disorders, ET-T tremor was noted in $2(7.7 \%)$ patients and EPT was found in $3(11.5 \%)$ patients. Tremor of EPT type was found in $80 \%$ of healthy subjects with tremor and 20\% had ET-T tremor.

Tremor among patients with neurodegenerative ataxias was found more commonly than in controls $(p=$ $=0.001)$; it was particularly true for postural tremor $(p=0.01)$ and ET-T tremor $(p=0.01)$. Tremor among HD patients or among patients with tic disorder was not more common than in controls $(p=0.9$ and $p=$ $=0.05$, respectively).

Tremor with asynchronous contractions of agonist and antagonist muscles was found in all patients with HD or with tic disorder and in $90.1 \%$ of patients with neurodegenerative ataxias. Neither severity of symptoms in patients with neurodegenerative ataxias, tic disorders, or $\mathrm{HD}$, nor impairment due to HD correlated with the severity of tremor $(p>0.05)$.

\section{Discussion}

This study is the first systematic assessment of prevalence, severity, types and forms of tremor using instrumental methods in neurodegenerative ataxias, $\mathrm{HD}$ and tic disorder. The limited published data related to the tremor in those conditions are derived mostly from case reports $[4,5,7,18]$.

Our study showed that upper limb tremor was significantly more common in patients with neurodegenerative ataxias only when compared with controls. Clinical assessment revealed presence of tremor in about $40 \%$ of those patients, and instrumental methods showed tremor in more than $50 \%$ of patients. This figure is consistent with most data found in the literature. Schols et al. [9] found postural and kinetic tremor in $50 \%$ out of 11 patients with SCA-2, Ruiz et al. [8] registered po stural tremor in 9 out of 23 patients with various types of SCA, and O'Hearn et al. [7] noted tremor in all 10 patients with SCA-12. Prevalence of upper limb tremor among patients with HD recorded in our study, both clinically and instrumentally, reached about $10 \%$ of studied patients and did not differ from the prevalence of tremor among controls. No study has been performed so far to assess the prevalence of tremor among patients with HD. Similarly, the prevalence of upper limb tremor among patients with tic disorder did not differ from that of controls, which is in agreement with the few available data. Two studies have been reported so far that addressed the prevalence of tremor in patients

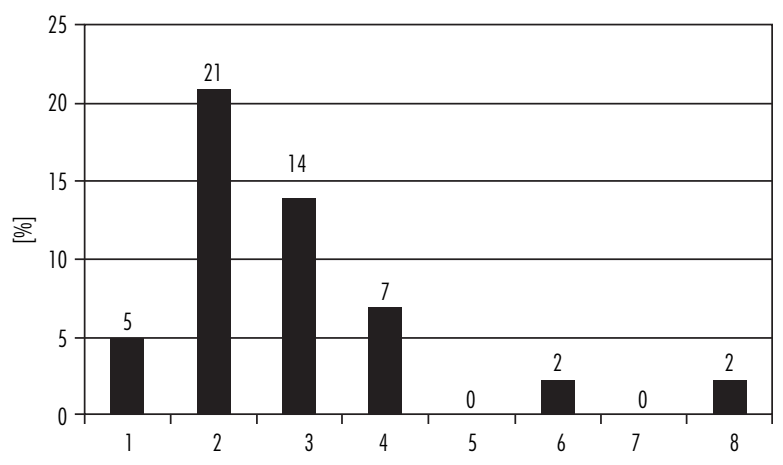

Fig. 3. Severity index of tremor assessed instrumentally with the graphic tablet in patients with degenerative ataxias

with tic disorder. Mejia and Jankovic [6] found ET-T tremor in $10.9 \%$ of 155 patients with tics. In the second study, Kulisevsky et al. [18] evaluated four patients with Tourette syndrome and found bilateral postural upper limb tremor with variable rhythm, frequency and amplitude in two patients and rest tremor resembling parkinsonian tremor in two other patients.

The results of our study show that in most cases of neurodegenerative ataxias postural tremor was present, while kinetic tremor was far less frequent and rest tremor was only noted sporadically, which is confirmed in the previous reports on the common prevalence of postural and kinetic tremor in SCA [7-9]. In some types of SCA, e.g. SCA-3, postural tremor was seen less frequently, i.e. in $8 \%$ of 80 patients. Rest tremor was noted rarely as well, i.e. in $6 \%$ of patients with SCA-3 and SCA-6 [9], but in as many as 3 out of 7 patients with SCA-2 [10]. Among patients with $\mathrm{HD}$ or with tic disorder, postural tremor was predominant but its prevalence was not different from that seen in controls.

The study reported here is the first one to analyse the prevalence of various types of tremor, such as ET-T or EPT in neurodegenerative ataxias, HD and tic disorder; therefore, no data from previous studies are available in the literature. Tremor observed in neurodegenerative ataxias, $\mathrm{HD}$ and tic disorder was the coincidence of those diseases and ET or EPT, which are common in the population but do not bother patients because of mild severity.

Papers published so far and related to the co-occurrence of tremor in movement disorders deal with Parkinson disease, dystonia and hemifacial spasm; postural tremor was predominant in those diseases and featured the characteristics of EPT or ET [18-27]. Our findings confirmed those results, showing the predominance of tremor of ET-T or EPT over tremor of another type. 
The common occurrence of ET-T tremor in neurodegenerative ataxias and in $\mathrm{HD}$ could also be explained by the coexistence of ET as an independent disorder. The prevalence of ET ranges from 0.4 to $4 \%$ in the general population $[28,29]$, although it may reach $5.5 \%$ among people aged at least 40 [30] or even $14 \%$ after the age of 65 [30]. ET is common in Parkinson disease $[19,20,23,27,31]$, dystonia [23], hereditary myoclonus and neuropathy [3], orthostatic tremor [34] or in other genetically determined diseases, e.g. Kennedy disease or restless legs syndrome [2]. Similarly, some members of families affected with ET were found to have typical ET, while in other members dystonia, parkinsonism or a combination of those three diseases was noted $[25,35]$. According to the analysis performed among 678 patients diagnosed with ET, coexistent Parkinson disease was found in $6.1 \%$, dystonia in $6.9 \%$, and myoclonus in $1.8 \%$ [36]. Yet other authors report that the postural tremor occurring in patients with Parkinson disease might be EPT [26].

Prevalence of physiological tremor and its parameters in the studied control group are consistent with the few published studies related to the prevalence of physiological tremor and EPT in healthy subjects. Enhanced physiological tremor in our study was also identified in $\mathrm{HD}$ and in tic disorder. Results of studies related to physiological tremor are difficult to interpret because of heterogeneous terminology applied in the literature and due to various methods of registration, as well as because of the various sensitivity of instruments. Some authors $[11,12,37]$ use the term 'physiological tremor' to describe the physiological occurrence of tremor in all subjects, which is invisible with the naked eye, but can be detected instrumentally. Those authors discern so-called EPT, which is revealed by hormonal changes, hypoglycaemia, stress, drugs and physical exercise. This tremor lasts longer but disappears after removal of the triggering factors. Other authors [38,39] use the term 'physiological tremor' to describe tremor which is invisible with the naked eye but can periodically appear during movements requiring unique precision. The last group commonly use this term to designate EPT. All authors agree, however, that the tremor has high frequency $(8-12 \mathrm{~Hz})$ and two tremor generators, the predominating peripheral and less active central one. The classification used in the present paper complies with the terminology of the first group of authors. Those studies confirmed the possibility of detection of physiological tremor which was not seen with the naked eye, and was identified with the clinically available instruments (EMG and accele- rometry). Previous studies, including Polish ones, showed that both accelerometry and EMG are methods that enable differentiation between pathological and physiological tremor, as well as the differentiation of particular types of pathological tremor [40,41]. Physiological tremor was registered in several percent of controls, in whom the severity of tremor did not reach the level of clinical manifestation (i.e. EPT). Two studies among large groups of healthy subjects, who were not exposed to factors inducing EPT (i.e. tremorogenic medications, drugs, tiredness, stress) assessed the prevalence of physiological tremor. Both studies used similar instrumental methods of tremor registration. Elble [14] demonstrated the presence of physiological tremor of upper limbs in about $10 \%$ of 200 tested healthy individuals tremor with the frequency of $8-12 \mathrm{~Hz}$ was seen most commonly, and among subjects older than 65 , tremor frequency of $6-8 \mathrm{~Hz}$ was often noted, which was difficult to differentiate from typical ET. On the other hand, Raethjen [13] studied 117 healthy subjects aged between 20 and 94 with an ac-celerometer and EMG and found that the instruments registered postural tremor of upper limbs with the frequency of 8-12 Hz, being physiological tremor, in $30 \%$ of healthy individuals. Similar findings in relation to the detection of physiological tremor in about $30 \%$ of subjects were reported by Louis [11].

Differences in the percentage of subjects with detected physiological tremor between the group reported here and studies by Raethjen [13] or Louis [11] could result from the difference in sample size and the sensitivity of instruments used.

In all groups of patients tremor had mild severity, assessed clinically as 1 point on a 4-point scale or instrumentally as about 2 points on a 10 -point scale. Similar mild intensity of tremor associated with movement disorders was reported elsewhere $[24,28,42,43]$.

Such a common coincidence of tremor with other movement disorders suggests that tremor is the most common additional sign in those disorders. It does not predominate in the clinical picture, as the mild severity or limited distribution (mostly in upper limbs) does not draw the attention of the physician or patient. Coexistence of tremor can often be detected with instrumental methods only. Mild severity of tremor, no impact on the quality of life or patient's activity result in neglect of that symptom both by the physician and the patient. Arduousness or sometimes disability due to the chorea, cerebellar ataxia or tics prompts patients to neglect less severe symptoms. It should be stressed that the instrumental testing revealed tremor in many patients in our group 
in whom tremor was not visible in clinical assessment. High sensitivity of instruments enabled us to detect tremor with mild severity, at the phase in which it shows up clinically only periodically (intermittent tremor) and could pass unnoticed by the physician or patient during the clinical examination, or tremor in the phase of internal tremor in which patients sense trembling invisible in clinical examination.

\section{Conclusions}

1. Tremor as the concomitant symptom among patients in the studied groups was much more common in patients with neurodegenerative ataxia than in controls, while its prevalence in patients with $\mathrm{HD}$ or with tic disorder was similar to that noted in healthy individuals.

2. Tremor in neurodegenerative ataxias has relatively mild severity; it is predominantly postural tremor of ET-T or other type of tremor. Essential tremor-like tremor predominates also in $\mathrm{HD}$ while in tic disorder the postural tremor features the EPT type.

3. Severity of tremor among patients with neurodegenerative ataxias, HD or tic disorder is mild and it is not related to the severity of the underlying disease.

4. Instrumental assessment of tremor enables the registration of tremor in an additional $10-20 \%$ of patients, in whom tremor is clinically invisible.

\section{Disclosure}

Authors report no conflict of interest.

\section{References}

1. Deuschl G., Bain P., Brin M. Consensus statement of the Movement Disorder Society on Tremor. Mov Disord 1998; 13 (Suppl 3): 2-23.

2. Ondo W.G., Lai D. Association between restless legs syndrome and essential tremor. Mov Disord 2006; 21: 515-518.

3. Cardoso F.C., Jankovic J. Hereditary moto-sensory neuropathy and movement disorders. Muscl Nerve 1993; 16: 904-910.

4. Siesling S., Vegter-van der Vlis M., Roos R.A. Juvenile Huntington disease in the Netherlands. Pediatr Neurol 1997; 17: 37-43.

5. Racette B.A., Perlmutter J.S. Levodopa responsive parkinsonism in an adult with Huntington's disease. J Neurol Neurosurg Psychiatry 1998; 65: 577-579.

6. Mejia N.I., Jankovic J. Secondary tics and tourettism. Rev Bras Psiquiatr 2005; 27: 11-17.

7. O'Hearn E., Holmes S.E., Calvert P.C., et al. SCA-12: tremor with cerebellar and cortical atrophy is associated with a CAG repeat expansion. Neurology 2001; 56: 299-303.
8. Ruiz P.J.G., Mayo D., Hernandez J., et al. Movement disorders in hereditary ataxias. J Neurol Sci 2002; 202: 59-64.

9. Schols L., Peters S, Szymanski S, et al. Extrapyramidal motor signs in degenerative ataxias. Arch Neurol 2000; 57: 1495-1500.

10. Lu C.S., Wu Chou Y.H., Kuo P.C., et al. The parkinsonian phenotype of spinocerebellar ataxia type 2. Arch Neurol 2004; 61: 35-38.

11. Louis E.D., Marder K., Cote L., et al. Prevalence of a history of shaking in persons 65 years of age and older: diagnostic and functional correlates. Mov Disord 1996; 11: 63-69.

12. Louis E.D., Ottman R., Hauser W.A. How common is the most common adult movement disorder?: estimates of the prevalence of essential tremor throughout the world. Mov Disord 1998; 13: $5-10$.

13. Raethjen J., Pawlas F., Lindemann M., et al. Determinants of physiologic tremor in a large normal population. Clin Neurophysiol 2000; 111: 1825-1837.

14. Elble R.J. Characteristics of physiologic tremor in young and elderly adults. Clin Neurophysiol 2003; 114: 624-635.

15. Elble R.J. Mechanism of physiological tremor and relationship to essential tremor. In: Findley L., Koller W. Handbook of tremor disorders. Marcel Dekker Inc., New York 1995, pp. 51-62.

16. Rudzińska M., Izworski A., Banaszkiewicz K., et al. Quantitative tremor analysis with a graphic digitizing tablet. Neurol Neurochir Pol 2007; 41: 510-516.

17. Timmer J., Lauk M., Deuschl G. Quantitative analysis of tremor time series. Electroencephalogr Clin Neurophysiol 1996; 101: 461-468.

18. Kulisevsky J., Berthier M.L., Avila A., et al. Unrecognized Tourette syndrome in adult patients referred for psychogenic tremor. Arch Neurol 1998; 55: 409-414.

19. Couch J.R. Dystonia and tremor in spasmodic torticolis. In: Eldridge R., Fahn S. [eds.]. Advances in neurology. Raven Press, New York 1976; 14: 245-258.

20. Geraghty J.J., Jankovic J., Zetusky W.J. Association between essential tremor and Parkinson's disease. Ann Neurol 1985; 17 : 329-333.

21. Jankovic J. Essentials tremor and Parkinson's disease. Ann Neurol 1989; 25: 211-215.

22. Chan J., Brin M.P., Fahn S. Idiopathic cervical dystonia: clinical characteristics. Mov Disord 1991; 6: 119-126.

23. Jankovic J. Essentials tremor and other movement disorders. In: Findley L.J., Koller W. [eds.]. Handbook of tremor disorders. Marcel Dekker, New York 1995, pp. 245-262.

24. Deuschl G., Heinen F., Guschlbauer B., et al. Hand tremor in patients with spasmodic torticollis. Mov Disord 1997; 12: 547552.

25. Jankovic J., Beach J., Pandolfo M., et al. Familial essential tremor in four kindreds: prospects for genetic mapping. Arch Neurol 1997; 54: 289-294.

26. Forssberg H., Ingvarsson P.E., Iwaski N., et al. Action tremor during object manipulation in Parkinson's disease. Mov Disord 2000; 15: 244-254.

27. Jankovic J. Essential tremor: clinical characteristics. Neurology 2000; 54 (Suppl 4): 22-26.

28. Rudzińska M., Wójcik M., Hartel M., et al. Tremor in hemifacial spasm patients. J Neural Transm 2011; 118: 241-247. 
29. Louis E.D., Marder K., Cote L., et al. Differences in the prevalence of essentials tremor among elderly African-Americans, Caucasians and Hispanics in Northern Manhattan. Arch Neurol 1995; 52: 1201-1205.

30. Dogu O., Sevim S., Camdeviren H., et al. Prevalence of essential tremor. Neurology 2003; 61: 1804-1806.

31. RautakorpiI., Takala J., Martilla R.J., et al. Essential tremor in a Finnish population. Acta Neurol Scand 1982; 66: 58-67.

32. Moghal S., Rajput A.H., D'Arcy C., et al. Prevalence of movement disorders in elderly community residents. Neuroepidemiology 1994; 13: 175-178.

33. Pahwa R., Koller W.C. Is there a relationship between Parkinson's disease and essential tremor? Clin Neuropharmacol 1993; 16: 30-35.

34. FitzGerald P.M., Jankovic J. Orthostatic tremor: An association with essential tremor. Mov Disord 1991; 6: 60-64.

35. Yahr M.D., Orosz D., Purohit D.P. Co-occurrence of essential tremor and Parkinson's disease: Clinical study of a large kindred with autopsy findings. Parkinsonism Relat Disord 2003; 9: 225-231.

36. Koller W.C., Busenbark K., Miner K., and the Essential Tremor Study Group. The relationship of essential tremor to other movement disorders: report on 678 patients. Ann Neurol 1994; 35 : 717-723

37. Smaga S. Tremor. Am Fam Physician 2003; 15: 1545-1552.

38. Elble R.J. The pathophysiology of tremor. In: Watts R.L., Koller W.C. [eds.]. Movement Disorders. Neurologic Principles and Practice. Mcgraw-Hill, New York 1997, pp. 405-417.

39. Manyam B. Uncommon forms of tremor. In: Watts R.L., Koller W.C. [eds.]. Movement Disorders. Neurologic Principles and Practice. Mcgraw-Hill, New York 2004, pp. 459-480.

40. Michałowska M. Wielogodzinne monitorowanie drżenia samoistnego i drżenia parkinsonowskiego. Neurol Neurochir Pol 2009. 43: 358-367.

41. Machowska-Majchrzak A., Pierzchała K., Pietraszek S. Analysis of selected parameters of tremor recorded by a biaxial accelerometer in patients with parkinsonian tremor, essential tremor and cerebellar tremor. Neurol Neurochir Pol 2007; 41: 241-250.

42. Deuechl G., Wenzelburger R., Loffler K., et al. Essential tremor and cerebellar dysfunction: clinical and kinematic analysis of intention tremor. Brain 2000; 123: 1568-1580.

43. Duval C. Rest and postural tremors in patients with Parkinson's disease. Brain 2006; 70: 44-48. 